\title{
THE EFFECT OF NB, TI, AL ON PRECIPITATION AND STRENGTHENING BEHAVIOR OF 718 TYPE SUPERALLOYS
}

\author{
Xishan Xie ${ }^{1}$, Jianxin Dong ${ }^{1}$, Gailian Wang ${ }^{1}$, Wei You ${ }^{1}$ \\ ${ }^{1}$ High Temperature Materials Research Laboratory \\ University of Science and Technology Beijing; Beijing 100083, China \\ Jinhui $\mathrm{Du}^{2}$ \\ ${ }^{2}$ Central Iron\&Steel Research Institute; Beijing 100081, China \\ Changhong Zhao ${ }^{3}$, Zhigang Wang ${ }^{3}$ \\ ${ }^{3}$ Fushun Specialty Steel Co.Ltd; Liaoning 113001, China \\ Tadeu Carneiro ${ }^{4}$ \\ ${ }^{4}$ Reference Metals Company; Bridgeville, PA15017, USA
}

Keywords: Modified 718, Associated Precipitation, Compact Morphology, Strengthening, Stability

\begin{abstract}
Inconel 718 characterizes with unique mechanical properties and has wild application in different high temperature industries. However, the ceiling temperature for Alloy 718 is $650 \mathrm{C}$ because of the instability of main strengthening phase $\gamma^{\prime \prime}-\mathrm{Ni}_{3}(\mathrm{Nb}, \mathrm{Ti}, \mathrm{Al})$. At high temperatures the metastable $\gamma^{\prime \prime}$ changes for stable phase $\delta-\mathrm{Ni}_{3} \mathrm{Nb}$ with large size and plate-like morphology. In result of that Alloy 718 looses structure stability and strengthening effect.

Recently, many researchers have studied the stability of Alloy 718 and try to develop modified 718 Alloys to be used beyond $650^{\circ} \mathrm{C}$. The basic idea of this paper is to raise the stability of $\gamma^{\prime \prime}$ and $\gamma^{\prime}$ strengthening phases in the following ways: raising the solution temperature of $\gamma^{\prime \prime}$ and $\gamma^{\prime}$, retarding the $\gamma^{\prime \prime}$ phase change for $\delta-\mathrm{Ni}_{3} \mathrm{Nb}$ and changing the precipitation behavior of $\gamma^{\prime \prime} / \gamma^{\prime}$ phase.

The experimental heats were prepared for this study in variation of $\mathrm{Nb}, \mathrm{Ti}, \mathrm{Al}$ and the atomic ratio among them on the base chemical composition of Alloy 718. The precipitated phase $\gamma^{\prime \prime}$ and $\gamma^{\prime}$ behavior was studied in detail by means of SEM and TEM and the weight fraction of $\gamma^{\prime \prime}+\gamma^{\prime}$ phases was exactly determined by electrolytic isolation and followed by micro-chemical analyses. The mechanical properties including hardness, tensile properties and stress rupture for several heats were also tested.

The structure of a new developed 718 type Alloy-Allvac ${ }^{\circledR} 718$ Plus ${ }^{\text {TM }}$ has been also adopted for comparison. A detail discussion has been conducted for 718 type superalloys in structure stability and strengthening effect both.
\end{abstract}

\section{Introduction}

Since Inconel718 was invented by H. Eiselstein ${ }^{[1]}$ in 1950 's and was put in application for aeroengines by GE and PWA companies in 1960's, Alloy 718 has got a wild application in different high temperature industries. However, Alloy 718 can not be used at the temperature higher than $650{ }^{\circ} \mathrm{C}$ because of the instability of main strengthening phase $\gamma^{\prime \prime}-\mathrm{Ni}_{3}(\mathrm{Nb}$, Ti, Al). At high temperatures the meta-stable $\gamma^{\prime \prime}$ changes for stable phase $\delta-\mathrm{Ni}_{3} \mathrm{Nb}$ with large size and plate-like morphology. In result of that Alloy 718 looses structure stability and strengthening effect. 
Since 1970's A. Pineau et. al ${ }^{[2]}$ studied the precipitation behavior of $\gamma^{\prime \prime}$ and $\gamma^{\prime}$ and intended to improve the structure stability of Alloy 718 at high temperature. In recent twenty years many researchers such as J. K. Tien ${ }^{[3,4]}$, Encai Guo ${ }^{[5,6]}$, Keh-Minn Chang ${ }^{[7]}$, Zhuangqi Hu and Wenru Sun ${ }^{[8]}$ studied the stability of Alloy 718 and try to develop modified 718 Alloys to be used beyond $650^{\circ} \mathrm{C}$. Recently Wei-Di Cao and R. Kennedy has developed a modified 718 Alloy to be used at $700{ }^{\circ} \mathrm{C}$ designated as Allvac ${ }^{\circledR} 718$ Plus $^{\text {TM }}{ }^{[9]}$. Xishan Xie and Jianxin Dong ${ }^{[10-14]}$ at the University of Science \& Technology Beijing systematically studied the modification of Alloy 718 as a long-term project in variation of main precipitation strengthening elements such as $\mathrm{Nb}$, $\mathrm{Al}$ and $\mathrm{Ti}$, solid solution strengthening elements $\mathrm{Mo}, \mathrm{W}$ and occasionally Co and also in control of minor elements such as $\mathrm{P}, \mathrm{S}$ and $\mathrm{Mg}{ }^{[15-18]}$.

This paper concentrates to study the effect of $\mathrm{Nb}, \mathrm{Ti}, \mathrm{Al}$ on precipitation and strengthening behavior of 718 type superalloys. The basic idea is to raise the stability of $\gamma^{\prime \prime} / \gamma^{\prime}$ strengthening phases in the following ways: raising solution temperature of $\gamma^{\prime \prime} / \gamma^{\prime}$, retarding $\gamma^{\prime \prime}$ phase change for $\delta-\mathrm{Ni}_{3} \mathrm{Nb}$ and changing the precipitation behavior of $\mathrm{Ni}_{3} \mathrm{M}\left(\gamma^{\prime \prime} / \gamma^{\prime}\right)$ phase.

$\mathrm{Ni}_{3} \mathrm{M}$ is an intermetallic phase, which can precipitate as strengthening phase in $\gamma$-matrix of most Ni-base superalloys. Where the element $\mathrm{M}$ can be $\mathrm{Al}, \mathrm{Ti}, \mathrm{Nb}, \mathrm{Ta}$ etc. However Ta is a strategic metal element and is most expensive among these 4 elements. From viewpoint of economics in most of cast/wrought superalloys $\mathrm{Al}, \mathrm{Ti}$ and $\mathrm{Nb}$ have been used as today's important strengthening elements for precipitation strengthening. $\mathrm{Ni}_{3} \mathrm{Al}$ with $\mathrm{FCC}$ structure is a stable strengthening phase which can precipitate in a wide aging temperature range and also very stable during long time exposure at high temperatures. $\mathrm{Nb}$ and $\mathrm{Ti}$ both have larger atomic size than that of Al. $\gamma^{\prime}-\mathrm{Ni}_{3}(\mathrm{Ti}, \mathrm{Al})$ or $\gamma^{\prime \prime}-\mathrm{Ni}_{3}(\mathrm{Nb}, \mathrm{Ti}, \mathrm{Al})$ can precipitate in coherence with $\gamma$-matrix and form an intensive strain field developing with excellent strengthening effect. However, $\gamma^{\prime}-\mathrm{Ni}_{3}(\mathrm{Ti}, \mathrm{Al})$ or $\gamma^{\prime \prime}-\mathrm{Ni}_{3}(\mathrm{Nb}, \mathrm{Ti}, \mathrm{Al})$ both are meta-stable phases and will change for stable phase $\eta-\mathrm{Ni}_{3} \mathrm{Ti}$ or $\delta$ $\mathrm{Ni}_{3} \mathrm{Nb}$ during long time exposure at high temperature. In result of that the precipitation strengthening effect of $\gamma^{\prime}-\mathrm{Ni}_{3}(\mathrm{Ti}, \mathrm{Al})$ and $\gamma^{\prime \prime}-\mathrm{Ni}_{3}(\mathrm{Nb}, \mathrm{Ti}, \mathrm{Al})$ will be seriously degraded. Seeking an excellent $\mathrm{Ni}_{3} \mathrm{M}$ precipitation strengthening in 718 type alloys is to control the $\mathrm{Nb}$, $\mathrm{Ti}$ and $\mathrm{Al}$ contents and to find a good combination of $\gamma^{\prime \prime} / \gamma^{\prime}$ precipitation for developing modified 718 alloys to be used beyond $650^{\circ} \mathrm{C}$. The structure stability behavior of investigated modified 718 alloys and the strengthening effect of $\gamma^{\prime \prime} / \gamma^{\prime}$ precipitation will be discussed in this paper.

\section{Materials and Experimental Procedure}

Alloy 718 basically characterizes with the chemical composition of $\mathrm{Ni} 19 \mathrm{Cr}-18 \mathrm{Fe}-3 \mathrm{Mo}-5.4 \mathrm{Nb}-$ 1Ti-0.5Al. Experimental heats investigated for this study are based on $\mathrm{Ni} 19 \mathrm{Cr}-18 \mathrm{Fe}-3 \mathrm{Mo}$ (occasionally adding $1.5 \% \mathrm{~W}$ ) with variation of $\mathrm{Nb}, \mathrm{Ti}$ and $\mathrm{Al}$ in the weight percentage range of $3.5-5.5 \% \mathrm{Nb}, 0.5-1.4 \% \mathrm{Ti}$ and $0.15-1.5 \% \mathrm{Al}$.

All laboratory heats $(15-20 \mathrm{Kg})$ were VIM melted, homogenized and finally hot rolled for 16$18 \mathrm{~mm}$ diameter bars for tests. For simplification a routine heat treatment for Alloy718 was still adopted for all modified Alloys as follows: $950^{\circ} \mathrm{C} / 1 \mathrm{~h} / \mathrm{AC}+720^{\circ} \mathrm{C} / 8 \mathrm{~h}\left(50^{\circ} \mathrm{C} / 1 \mathrm{~h} \mathrm{~F}\right.$ F.C. $) \rightarrow 620^{\circ} \mathrm{C}$ $18 \mathrm{~h} / \mathrm{AC}$. Long time exposures were conducted after heat treatment at the temperatures above $6500^{\circ} \mathrm{C}$ till to $760^{\circ} \mathrm{C}$ for tens to several hundred hours. Hardness measurement was conducted as a simple evaluation for strengthening effect. Mechanical tests including tensile and stress rupture were also conducted for some heats. The phase existing range and its solvus temperature at equilibrium condition were calculated by Thermo-Calc software. Microstructrue characterization was conducted by SEM, XRD and TEM. The average size of strengthening precipitates of $\gamma^{\prime \prime}$ and 
$\gamma^{\prime}$ were quantitatively determined by TEM images. The weight fractions of precipitated phases in modified 718 Alloys were determined by the quantitative method of phase extraction and microchemical phase analyses.

\section{Result and Discussion}

Investigated 718 Type Alloys (in at $\%$ )

In consideration of precipitated phase formation, all investigated 718 type alloys with variation of $\mathrm{Nb}$, $\mathrm{Ti}$ and $\mathrm{Al}$ (in at\%) can be expressed in Fig. 1 of $\mathrm{S}$ and $\mathrm{R}$ coordinate, where $\mathrm{S}$ is the sum of $(\mathrm{Al}+\mathrm{Ti}+\mathrm{Nb})$ in at $\%$ and $\mathrm{R}$ is the atomic percentage ratio of $(\mathrm{Al}+\mathrm{Ti}) / \mathrm{Nb}$. Conventional Alloy 718 with $5.0-5.5 \% \mathrm{Nb}, 1 \% \mathrm{Ti}$ and $0.5 \% \mathrm{Al}$ (in $\mathrm{wt}^{\mathrm{O}} \%$ ) is located in the lower left part (as circled in Fig.1), which characterizes with low sum of $\mathrm{Al}+\mathrm{Ti}+\mathrm{Nb}(\mathrm{S} \approx 5.5 \mathrm{at} \%)$ and also low ratio of the $(\mathrm{Al}+\mathrm{Ti}) / \mathrm{Nb}(\mathrm{R} \approx 0.7)$. For strengthening stable $\gamma^{\prime}$ precipitation, $\mathrm{Al}$ and $\mathrm{Ti}$ contents were raised to a higher levels of $\mathrm{S}$ and $\mathrm{R}$ and also with high content of $\mathrm{Nb}$ for $\gamma^{\prime \prime}$ strengthening in experimental heats as indicated

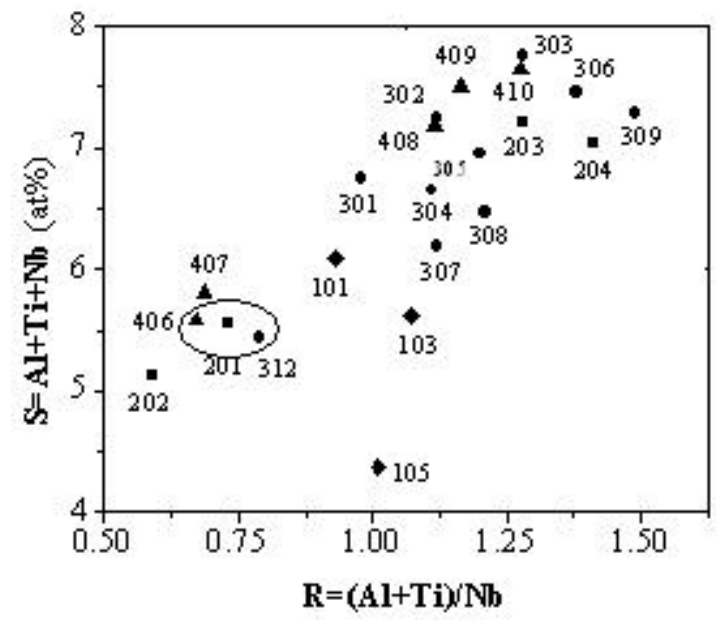

Fig.1 Investigated 718 type alloys in the coordinate of $\mathrm{S}=(\mathrm{Al}+\mathrm{Ti}+\mathrm{Nb})$ in $\mathrm{at} \%$ and $\mathrm{R}=(\mathrm{Al}+\mathrm{Ti}) / \mathrm{Nb}$ in the right top corner in Fig.1. The highest sum of $(\mathrm{Al}+\mathrm{Ti}+\mathrm{Nb}) \%$ at and ratio of $(\mathrm{Al}+\mathrm{Ti}) / \mathrm{Nb}$ for experimental heat is about 7.75 and 1.5, respectively. These data $\mathrm{S}$ and $\mathrm{R}$ are much higher than that of Alloy 718. We expect to get more $\gamma^{\prime}$ precipitation strengthening effect at higher ratio of $(\mathrm{Al}+\mathrm{Ti}) / \mathrm{Nb}$ and more fraction of precipitated $\gamma^{\prime \prime} / \gamma^{\prime}$ phase at higher sum of $(\mathrm{Al}+\mathrm{Ti}+\mathrm{Nb}) \%$ at in these investigated alloys. However, when the sum of $(\mathrm{Al}+\mathrm{Ti}+\mathrm{Nb}) \%$ at is higher than $7.5 \%$, these alloys were very difficult to forge and even break down during hot working process.

\section{Mechanical Properties}

Experimental results show that for high strength keeping in 718 type alloys the $\mathrm{Nb}$ content should be controlled at a high level (such as 5.4-5.5\%wt). Fig. 2 shows the effect of $(\mathrm{Al}+\mathrm{Ti}+\mathrm{Nb})$ $\%$ at (for a group of modified 718 alloys at high level of $\mathrm{Nb}, 5.4-5.5 \% \mathrm{wt}$ ) on $6500^{\circ} \mathrm{C}$ tensile strengths.

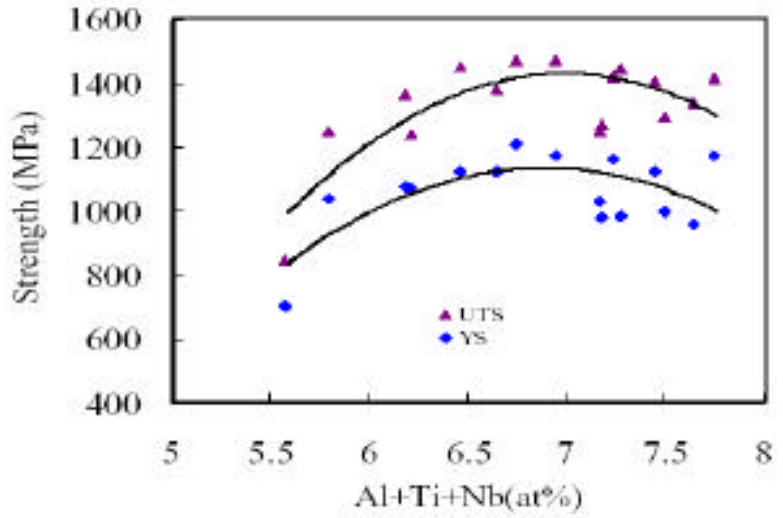

Fig. 2 Effect of the sum of $(\mathrm{Al}+\mathrm{Ti}+\mathrm{Nb}) \%$ at on $650^{\circ} \mathrm{C}$ tensile strength in modified 718 type alloys

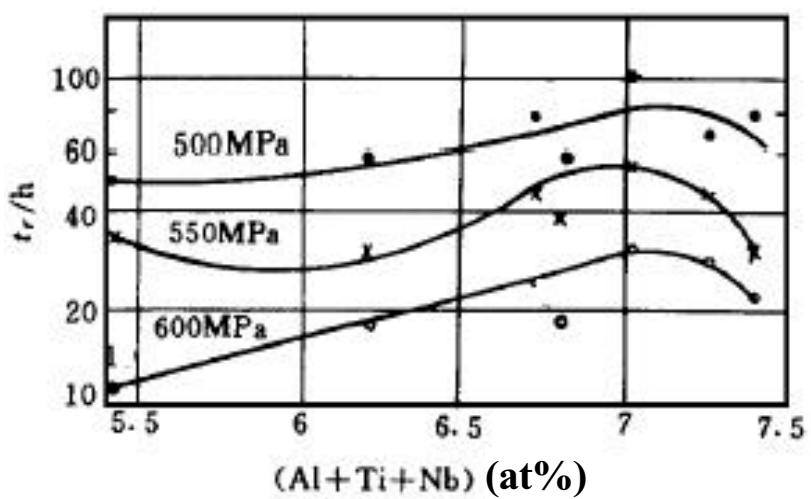

Fig.3 Effect of the sum of $(\mathrm{Al}+\mathrm{Ti}+\mathrm{Nb}) \%$ at on $700{ }^{\circ} \mathrm{C}$ stress rupture lives in modified 718 type alloys 
It can be seen that yield and ultimate strengths are very dependent on the sum of $(\mathrm{Al}+\mathrm{Ti}+\mathrm{Nb})$ $\%$ at. When $(\mathrm{Al}+\mathrm{Ti}+\mathrm{Nb}) \%$ at is in the range of 7-7.5 (at \%), the highest tensile yield and ultimate strength can be reached. Fig. 3 shows the result from other group of alloys that the $700{ }^{\circ} \mathrm{C}$ stress rupture lives at 500, 550 and $600 \mathrm{MPa}$ also raise with the sum of $(\mathrm{Al}+\mathrm{Ti}+\mathrm{Nb}) \%$ at. These results indicate that either tensile strengths or stress rupture lives at high temperatures are sensitively dependent on the sum of $(\mathrm{Al}+\mathrm{Ti}+\mathrm{Nb}) \%$ at. For high strengths of modified 718 type alloys the sum of $(\mathrm{Al}+\mathrm{Ti}+\mathrm{Nb}) \%$ at should be kept in a high range of 7-7.5\%at at the high level of $\mathrm{Nb}(5.4-$ $5.5 \% \mathrm{wt})$. However, the sum of $(\mathrm{Al}+\mathrm{Ti}+\mathrm{Nb}) \%$ at in conventional Alloy 718 is only about 5.5$5.6 \%$ at as indicated in Fig.1. At high content level of $\mathrm{Nb}(5.4-5.5 \% \mathrm{wt})$ for raising the sum of $(\mathrm{Al}+\mathrm{Ti}+\mathrm{Nb}) \%$ at the contents of $\mathrm{Al}$ and $\mathrm{Ti}$ should be raised obviously. As indicated in Fig.1 the major experimental heats are shifted to the high levels of $(\mathrm{Al}+\mathrm{Ti}+\mathrm{Nb}) \%$ at and $(\mathrm{Al}+\mathrm{Ti}) / \mathrm{Nb}$ both (see Fig.1 right corner).

\section{$\underline{\text { Structure Design and Evaluation }}$}

SEM Observation Typical SEM structure of Alloy 718, where (Al+Ti+Nb)\%at(S) is about $5.5 \%$ at and the ratio( $\mathrm{R})(\mathrm{Al}+\mathrm{Ti}) / \mathrm{Nb}$ is about 0.7 , characterizes with grain boundary precipitation of $\delta-\mathrm{Ni3} \mathrm{Nb}$ in short rods and globular morphology(see Fig.4a). The main fine precipitates of disk-like $\gamma^{\prime \prime}$ and a supplementary precipitation of fine globular $\gamma^{\prime}$ can not be detected because of the low resolution of SEM. With increasing of $\mathrm{Al}$ and Ti contents both the higher level of $(\mathrm{Al}+\mathrm{Ti}+\mathrm{Nb}) \%$ at can be reached in our investigated modified 718 alloys the plate-like phase precipitation and sometimes lamellar precipitation can also form at grain boundaries (sometimes in the grains) as indicated in Fig.4b. Fig.4c shows similar picture to Fig.4b in a modified 718 alloy with almost same contents of $\mathrm{Al}, \mathrm{Ti}$ and $\mathrm{Nb}$ in alloy of Fig. $4 \mathrm{~b}$ except adding $1.5 \mathrm{wt} \% \mathrm{~W}$. This long plate-like grain boundary precipitates and lamellar structure of precipitates also well developed in Allvac Alloy 718PlusB and 718PlusA(see Fig.4d and 4F) conducted with higher aging temperatures than Alloy718. Investigated heat with higher content of $\mathrm{Al}$ ( $1.44 \mathrm{wt} \% \mathrm{Al}$ and also by adding $1.5 \mathrm{wt} \% \mathrm{~W}$ can still keep similar grain boundary precipitation behavior as Alloy718(see Fig.4a and 4e). All modified 718 alloys (Fig.4b,c,d,e and f) keep high levels of the sum of $\mathrm{Al}+\mathrm{Ti}+\mathrm{Nb}(7.2-7.6 \%$ at) and the ratio of $(\mathrm{Al}+\mathrm{Ti}) / \mathrm{Nb}(1.1-1.28)$ in comparison with conventional Alloy718. the above mentioned S and R parameters in those modified 718 alloys are almost $40 \%$ and $60 \%$ higher than that in Alloy 718 respectively. In result of that the precipitation behavior changes obviously in modified 718 type alloys.

Fraction of Strengthening Phases The fractions of strengthening phases $\gamma^{\prime \prime} / \gamma^{\prime}$ precipitated in modified 718 type alloys are very dependent on the sum of $\mathrm{Al}+\mathrm{Ti}+\mathrm{Nb}$ in atomic percentage. Experimental results from quantitative determination by electrolytic isolation of precipitates and followed by micro-chemistry analyses are shown in Fig5. The weight fractions of $\gamma^{\prime \prime} / \gamma^{\prime}$ are continuously raised with increasing of $(\mathrm{Al}+\mathrm{Ti}+\mathrm{Nb}) \%$ at. In conventional Alloy 718 with low level of $\mathrm{Al}+\mathrm{Ti}+\mathrm{Nb}\left(5.5-5.6 \%\right.$ at) the fraction of $\gamma^{\prime \prime} / \gamma^{\prime}$ is in the low range of $14-15 \% \mathrm{wt}$. However, for modified 718 alloys the $\gamma^{\prime \prime} / \gamma^{\prime}$ fractions can almost reach 20\% even higher. The $\gamma^{\prime \prime} / \gamma^{\prime}$ fraction of a new developed Allvac 718Plus(with 1.46\%Al, 0.74\% Ti, 5.48\%Nb, 1.04\%W, 9.13\%Co in wt \%) has been determined as $21 \%$. The $\gamma^{\prime \prime} / \gamma^{\prime}$ fractions in these modified 718 alloys $(\sim 20 \% \mathrm{wt})$ are almost $1 / 3$ higher than conventional 718 Alloy $\left(14-15 \% \gamma^{\prime \prime}+\gamma^{\prime}\right)$. It has convinced us that these modified 718 type alloys characterize with high strengths not only high temperature tensile strengths but also in stress rupture lives as indicated in Fig.2 and Fig.3.

$\underline{\mathrm{Ni}_{3}}$ M Phase Identification It has been indicated in Fig.4 that the precipitated phase in short rods, plates and sometimes lamellar structure morphology can form at different $\mathrm{Al}$ and $\mathrm{Ti}$ content combination. In conventional Alloy 718 only $\delta-\mathrm{Ni}_{3} \mathrm{Nb}$ type $\mathrm{Ni} \mathrm{M}$ forms because of its high content of $\mathrm{Nb}$ and low ratio of $(\mathrm{Al}+\mathrm{Ti}) / \mathrm{Nb}$, which is about 0.7 only. $\delta-\mathrm{Ni}_{3} \mathrm{Nb}$ phase can be also 

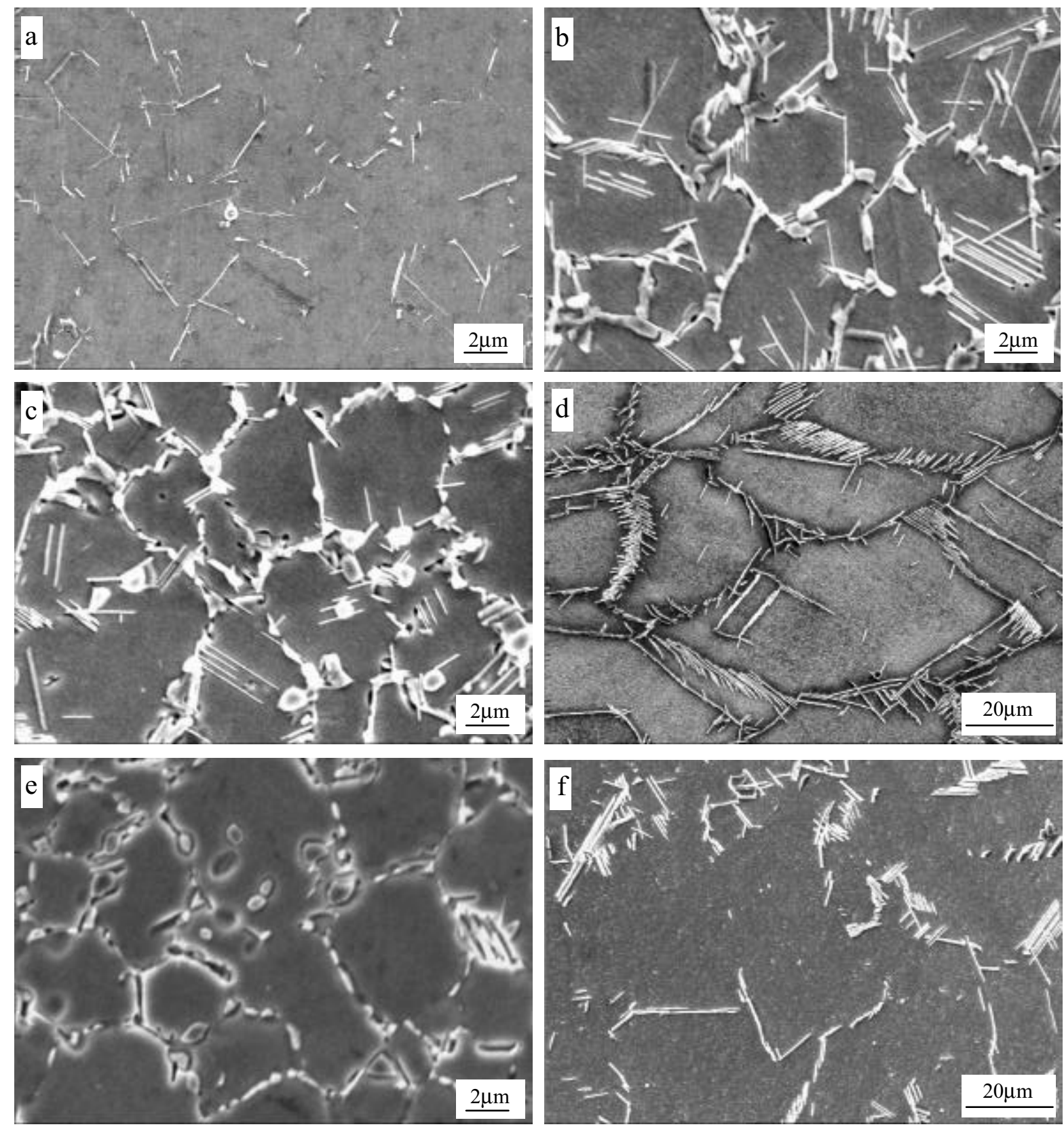

Fig.4 Effect of $\mathrm{Al}$ and $\mathrm{Ti}$ on SEM structure with grain boundary precipitation behavior of modified 718 alloys $(5.4-5.5 \mathrm{wt} \% \mathrm{Nb})$ at as heat-treated condition

found in modified 718 alloys because the high content of $\mathrm{Nb}(5.4-5.5 \% \mathrm{wt})$ is still remained. When the ratio of $(\mathrm{Al}+\mathrm{Ti}) / \mathrm{Nb}$ becomes higher in modified 718 alloys with high sum of $\mathrm{Al}+\mathrm{Ti}+\mathrm{Nb}(7-7.5 \%$ at) such as $\mathrm{R}=1.1-1.3$, the other type of $\mathrm{Ni} \mathrm{M}$ can be found. In the case of high content of $\mathrm{Al}$ (such as Allvac 718PlusA and 718PlusB) the $\mathrm{Ni}_{3} \mathrm{Al}_{0.5} \mathrm{Nb}_{0.5}$ (HCP) phase has been identified ${ }^{[19,20]}$ (see Fig.6b,6c), which is different to $\delta-\mathrm{Ni}_{3} \mathrm{Nb}$ not only in chemical composition but also in crystallographic structure, however its morphology is very similar to $\delta-\mathrm{Ni}_{3} \mathrm{Nb}$.

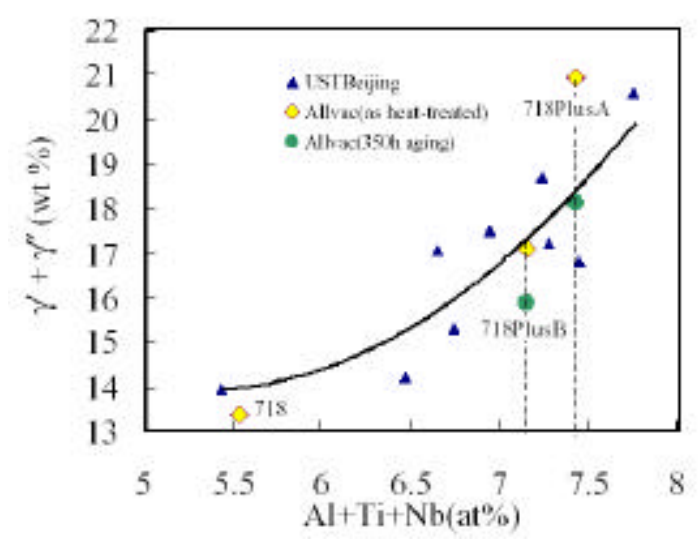

Fig.5 The relationship of the $\gamma^{\prime \prime} / \gamma^{\prime}$ fraction on the sum of $(\mathrm{Al}+\mathrm{Ti}+\mathrm{Nb}) \%$ at 


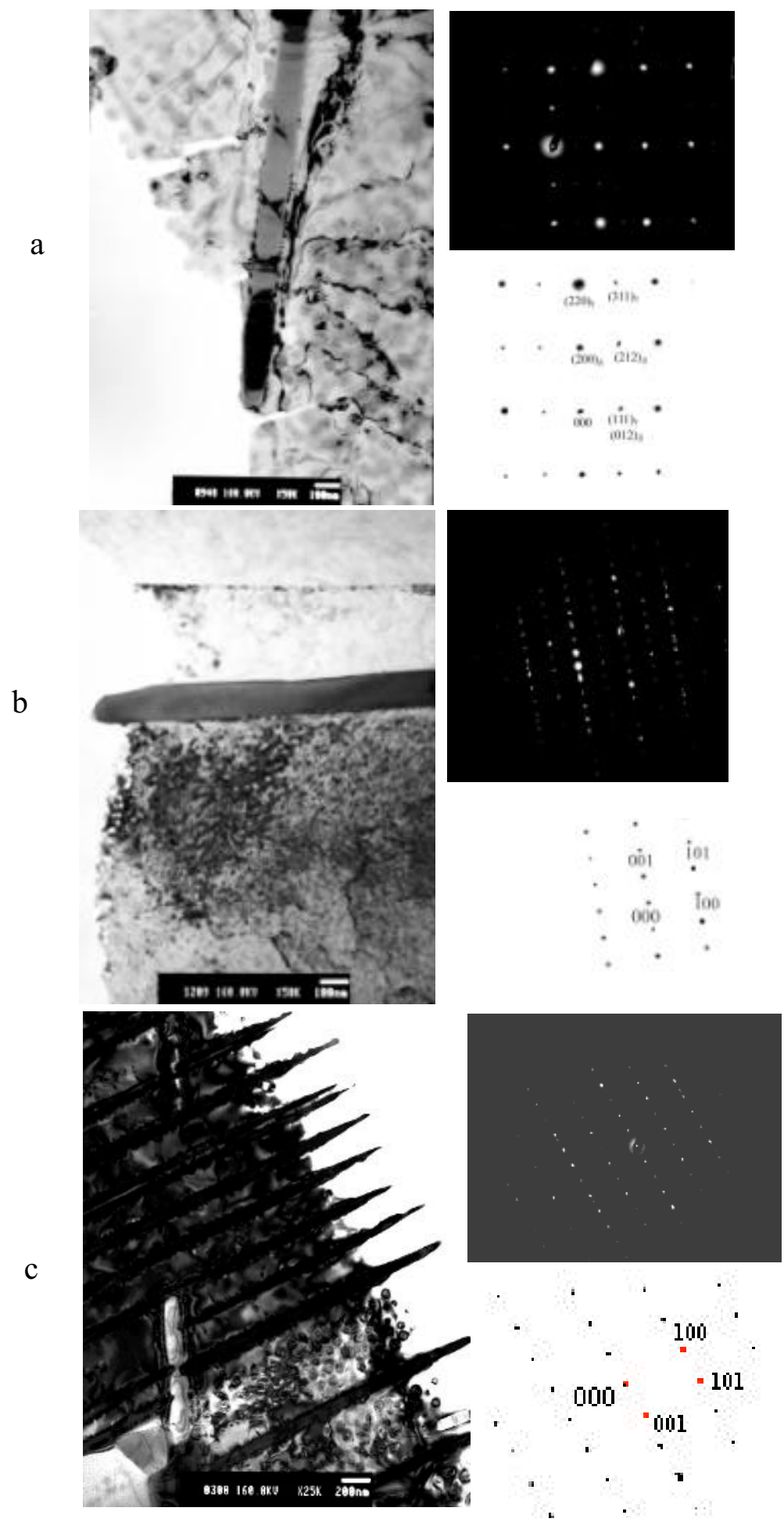

Fig. 6 the $\mathrm{Ni}_{3} \mathrm{M}$ phase identified as $\delta-\mathrm{Ni}_{3} \mathrm{Nb}$ (orthorhornbic), $\mathrm{Ni}_{3} \mathrm{Al}_{0.5} \mathrm{Nb}_{0.5}(\mathrm{HCP})$ in Alloy718 and Modified 718 Alloys

(a) $\delta-\mathrm{Ni}_{3} \mathrm{Nb}$ (Orthorhombic) identified in Alloy 718 and Modified 718 Alloys

(b) $\mathrm{Ni}$ M- $\mathrm{Ni}_{3} \mathrm{Al}_{0.5} \mathrm{Nb}_{0.5}$ (HCP) identified in Allvac 718PlusA

(c) Lamellar $\mathrm{Ni}_{3} \mathrm{Al}_{0.5} \mathrm{Nb}_{0} 5$ (HCP) identified in Allvac 718PlusB

$\gamma^{\prime \prime}$ and $\gamma^{\prime}$ Precipitation Behavior Conventional Alloy 718 characterizes with large portion of disc-like $\gamma^{\prime \prime}$ precipitation and supplementary precipitation of $\gamma^{\prime}$. With the variation of $\mathrm{Al}$ and $\mathrm{Ti}$ 
contents in modified 718 alloys, the $\gamma^{\prime \prime}$ and $\gamma^{\prime}$ precipitation behavior changes. There are other 3 types of $\gamma^{\prime \prime}$ and $\gamma^{\prime}$ precipitation as follows:

(1) Associated precipitation of $\gamma^{\prime \prime}$ and $\gamma^{\prime} \cdot \gamma^{\prime \prime}$ can be bound up with almost hemispherical $\gamma^{\prime}$ or can alternatively precipitate as a "sandwich" morphology as shown in Fig.7a and 7b.

(2) Compact morphology of $\gamma^{\prime \prime}$ and $\gamma^{\prime}: \gamma^{\prime \prime}$ can directly precipitate at cuboid shaped $\gamma^{\prime}$ particles coated with its shell as shown in Fig.7c

(3) Mainly $\gamma^{\prime}$ precipitation: Fig.7d shows typical fine globular $\gamma^{\prime}$ precipitation in a modified 718 alloy Allvac $718 \mathrm{Plus}$ with high sum of $\mathrm{Al}+\mathrm{Ti}+\mathrm{Nb}(7.43 \mathrm{at} \%)$ and high ratio of $(\mathrm{Al}+\mathrm{Ti}) / \mathrm{Nb}(1.17)$ and also high ratio of $\mathrm{Al} / \mathrm{Ti}(3.65)$.

It can be seen from Fig.7 that the $\gamma^{\prime \prime}$ and $\gamma^{\prime}$ precipitation behavior is very dependent on $\mathrm{Al}$ and $\mathrm{Ti}$ contents. It can be changed from separate precipitation of $\gamma^{\prime \prime}$ and $\gamma^{\prime}$ (as in Alloy718) to associated precipitation of $\gamma^{\prime \prime}+\gamma^{\prime}$ (see Fig.7a and 7b), compact morphology of $\gamma^{\prime \prime}+\gamma^{\prime}$ (see Fig.7c) and mainly globular $\gamma^{\prime}$ precipitation(see Fig.7d). The precipitation behavior of $\gamma^{\prime \prime}$ and $\gamma^{\prime}$ sensitively depends on $\mathrm{Al}+\mathrm{Ti}$ content and especially the atomic percentage ratios of $(\mathrm{Al}+\mathrm{Ti}) / \mathrm{Nb}$ and $\mathrm{Al} / \mathrm{Ti}$ in modified 718 type alloys.

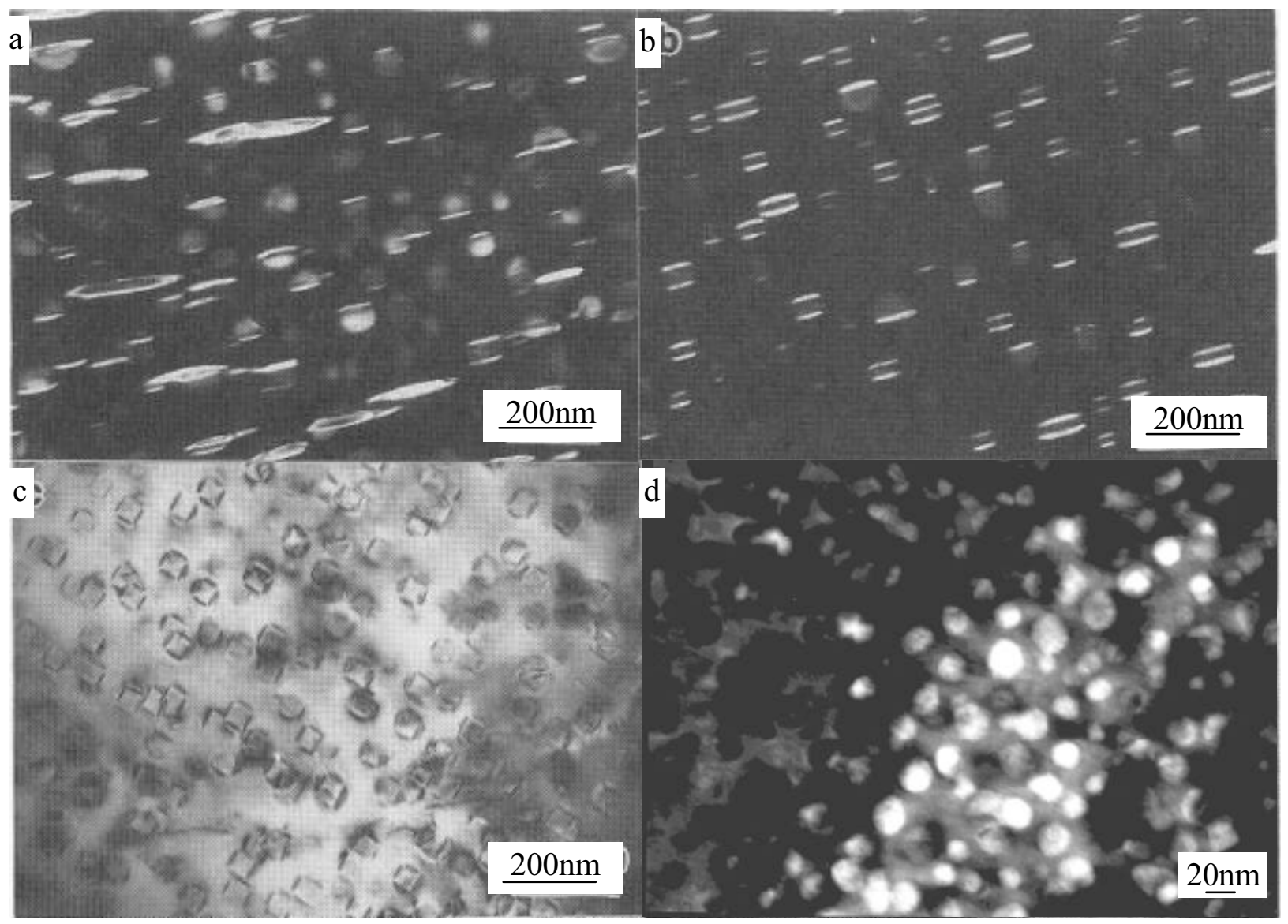

Fig. $7 \gamma^{\prime \prime} / \gamma^{\prime}$ precipitation behavior in modified 718 alloys

(a) (b) Associated Precipitation of $\gamma^{\prime \prime} / \gamma^{\prime}$ in Modified 718 Alloys;

(c) Compact Morphology of $\gamma^{\prime \prime} / \gamma^{\prime}$ precipitation in Modified 718 Alloy;

(d) Typical $\gamma^{\prime}$ Precipitation in Allvac 718Plus 
The Al and Ti contents in modified 718 alloy not only change the precipitation behavior of $\gamma^{\prime \prime}$ and $\gamma^{\prime}$ but also the solvus temperature of $\gamma^{\prime \prime} / \gamma^{\prime}$, which can be calculated from Thermo-Calc software. However Thermo-Calc calculated data can be presented as equilibrium precipitated phase $\gamma^{\prime}$ only. Table 1 shows the effect of Al content on the solvus temperatures of $\gamma^{\prime}\left(\gamma^{\prime \prime}\right)$ in modified 718 alloys. When the Al content is raised from $0.5 \%$ to $1.5 \%$ wt. The $\gamma^{\prime}\left(\gamma^{\prime \prime}\right)$ solvus temperature can be raised from $899^{\circ} \mathrm{C}$ (for Alloy718) to $987^{\circ} \mathrm{C}$ (for modified 718 Alloy). It is almost raised $100{ }^{\circ} \mathrm{C}$ for a modified 718 alloy, which should show better structure stability at high temperature long time exposure.

Table 1 Effect of Al Content(in wt $\%)$ on $\gamma^{\prime}\left(\gamma^{\prime \prime}\right)$ Solvus Temperatures in Modified 718 alloy

\begin{tabular}{|c|c|c|c|}
\hline \multirow{2}{*}{ Alloys } & Alloy718 & \multicolumn{2}{|c|}{ Modified 718 Alloy } \\
\cline { 3 - 4 } & $0.5 \mathrm{Al}$ & $1.0 \mathrm{Al}$ & $1.5 \mathrm{Al}$ \\
\hline$\gamma^{\prime}\left(\gamma^{\prime \prime}\right)$ solvus( $\left.\mathrm{C}\right)$ & 899 & 958 & 987 \\
\hline
\end{tabular}

Structure Stability $\gamma^{\prime \prime}$ precipitation characterizes with unique strengthing effect because of high coherency strain strengthening developed by the large mismatch between $\gamma^{\prime \prime}$ and $\gamma$-matrix. However, from viewpoint of phase stability $\gamma^{\prime \prime}$ is a meta-stable phase, which transforms to stable $\delta-\mathrm{Ni}_{3} \mathrm{Nb}$ at high temperature, especially above $650^{\circ} \mathrm{C}$ for conventional 718 Alloy. In result of that the strengthening effect decreases and the high temperature mechanical properties especially stress rupture lives above $650^{\circ} \mathrm{C}$ are seriously degraded for Alloy718. $\mathrm{Ni}_{3} \mathrm{Al}$ type $\gamma^{\prime}$ precipitation characterizes with more stable strengthening effect than $\gamma^{\prime \prime}$ at higher temperatures. From viewpoint of structure design for stability improvement to modified 718 type alloys to be use above $650^{\circ} \mathrm{C}$, an associated precipitation of $\gamma^{\prime \prime}+\gamma^{\prime}$ or a compact morphology of precipitated $\gamma^{\prime \prime}+\gamma^{\prime}$ even mainly $\gamma^{\prime}$ precipitation strengthening is essentially required. The method to meet this requirement is to adjust $\mathrm{Al}, \mathrm{Ti}$ and $\mathrm{Nb}$ in development of modified 718 type alloys.

Fig. 8 shows strengthening effect comparison in the temperature range of $730-800 \mathrm{C}$ for $50 \mathrm{hrs}$ thermal aging. The hardness of Alloy 718 (Heat312, 5.14Nb, 1.03Ti, 0.46Al in wt $\%$ ) seriously decreases with the temperature raising because of the rapid coarsening of main strengthening $\gamma^{\prime \prime}$ separately precipitated in $\gamma$-matrix. However a modified 718 alloy (Heat305, 5.14Nb, 1.16Ti,

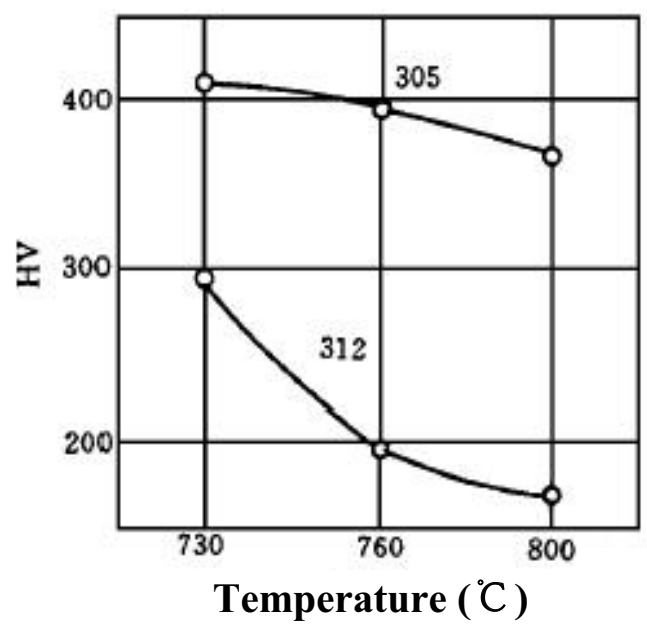

Fig8. Hardness comparison of a modified 718 alloy(Heat305) with conventional 718 Alloy after $50 \mathrm{~h}$ thermal aging at $730-800^{\circ} \mathrm{C}$

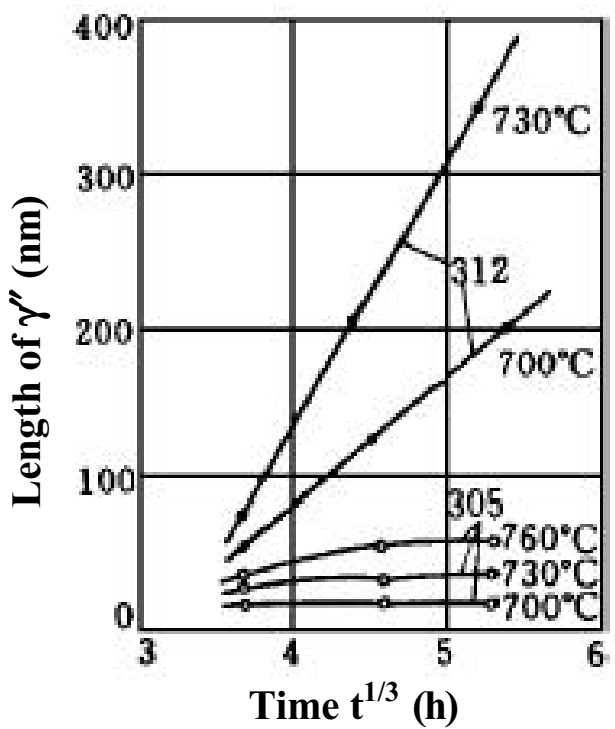

Fig9 Coarsening rate comparison of a modified 718 alloy(Heat305) with conventional 718 
$1.13 \mathrm{Al}$ in $\mathrm{wt} \%$ ) with associated precipitation of $\gamma^{\prime \prime}+\gamma^{\prime}$ characterizes with much higher hardness than Alloy 718 after $50 \mathrm{~h}$ aging at the temperatures $730-800^{\circ} \mathrm{C}$. The coarsening rate comparison of the modified alloy (Heat 305) with Alloy718 (Heat 312) at the temperature 700, 730 and $760 \mathrm{C}$ (Fig 9) express the unique structure stability of this modified 718 alloy with high content of Al. The TEM precipitation phases behavior comparison (Fig.10) shows a clear understanding that an associated precipitation of $\gamma^{\prime \prime}+\gamma^{\prime}$ (as "sand wich" morphology of $\gamma^{\prime \prime}+\gamma^{\prime}$ ) characterizes with much better structure stability than that of separately precipitated $\gamma^{\prime \prime}$ and $\gamma^{\prime}$ in conventional 718 Alloy.

$\mathrm{Al}$ and $\mathrm{Ti}$ both can form $\mathrm{Ni}(\mathrm{Al}, \mathrm{Ti})$ type $\gamma^{\prime}$ precipitation strengthening. Al can stabilize $\gamma^{\prime}$ formation, however at higher content of $\mathrm{Ti}$ in modified 718 alloys the $\mathrm{Ni}$ (Al,Ti) type $\gamma^{\prime}$ strengthening phase may transform in long plate-like $\mathrm{Ni}_{3} \mathrm{M}(\mathrm{HCP})$ phase and sometimes in a morphology of cellular precipitation even the formation of Widmansttaten structure in $\gamma$ matrix(see Fig.11). In result of that the $\gamma^{\prime}$ strengthening effect will be obviously degraded.
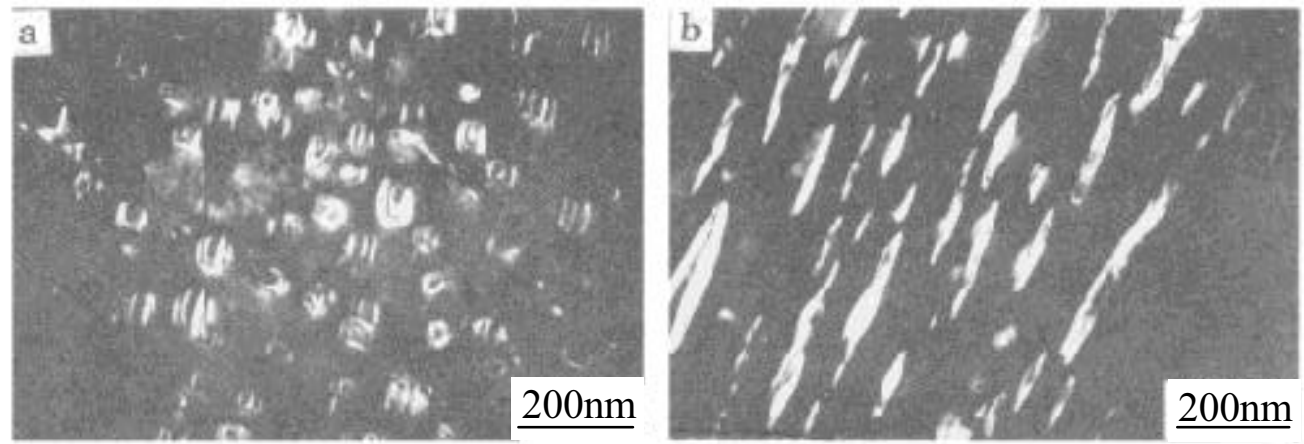

Fig.10 TEM structure comparison of a modified 718 alloy(a-Heat305) with conventional 718 Alloy(b-Heat312) after 50hrs aging at $760^{\circ} \mathrm{C}$
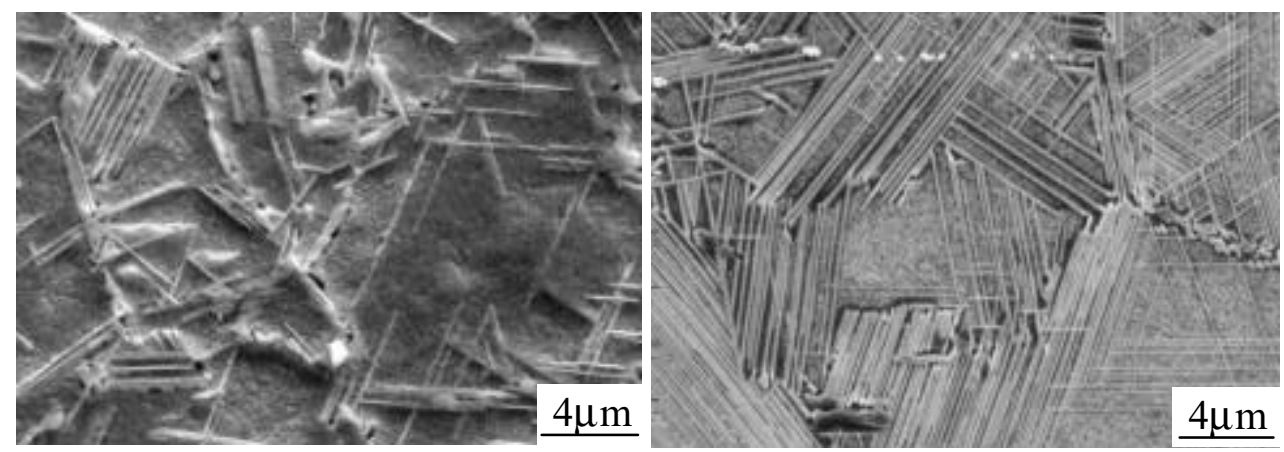

Fig.11 Effect of $\mathrm{Ti}$ on plate-like $\mathrm{N}_{3} \mathrm{M}$ phase formation in modified 718 type alloys

(a) Modified 718 alloy Heat $408(5.47 \mathrm{Nb}, 1.37 \mathrm{Ti}, 1.0 \mathrm{Al}$ inwt $\%$ ) after $680 \mathrm{C} / 500 \mathrm{~h}$ aging;

(b) Allvac $718 \mathrm{PlusB}\left(5.48 \mathrm{Nb}, 1.14 \mathrm{Ti}, 1.08 \mathrm{Al}\right.$ and $9.13 \mathrm{Co}, 1.04 \mathrm{~W}$ in wt $\%$ ) after $760{ }^{\circ} \mathrm{C} / 500 \mathrm{~h}$ aging

From viewpoint of structure stability design and precipitation strengthening effect keeping for modified 718 alloy development to be used above $650^{\circ} \mathrm{C}$. The one of the simplest methods is to control the $\gamma^{\prime \prime}$ and $\gamma^{\prime}$ phase precipitation behavior by means of the adjustment of $\mathrm{Nb}$, Ti and Al. For high temperature strengths in tensile and stress rupture both, $\mathrm{Nb}$ content in modified 718 alloys should be kept at the high level $(5.4-5.5 \mathrm{wt} \% \mathrm{Nb})$. To strengthen the $\gamma^{\prime}$ precipitation in $\gamma^{\prime \prime}+\gamma^{\prime}$ strengthening effect the $\mathrm{Al}$ and $\mathrm{Ti}$ contents should be raised. However, Ti promotes the instability of $\gamma^{\prime}$ and the formation of large and long plate-like phase $\mathrm{Ni}$ M. In consideration of that, the Ti content is suggested to be controlled at a medium level( $\sim 1 \mathrm{wt} \%$ or less $)$. The Al content can be raised from $0.5 \%$ wt in alloy 718 to a higher level $(1-1.5 \% \mathrm{wt})$ in modified 718 


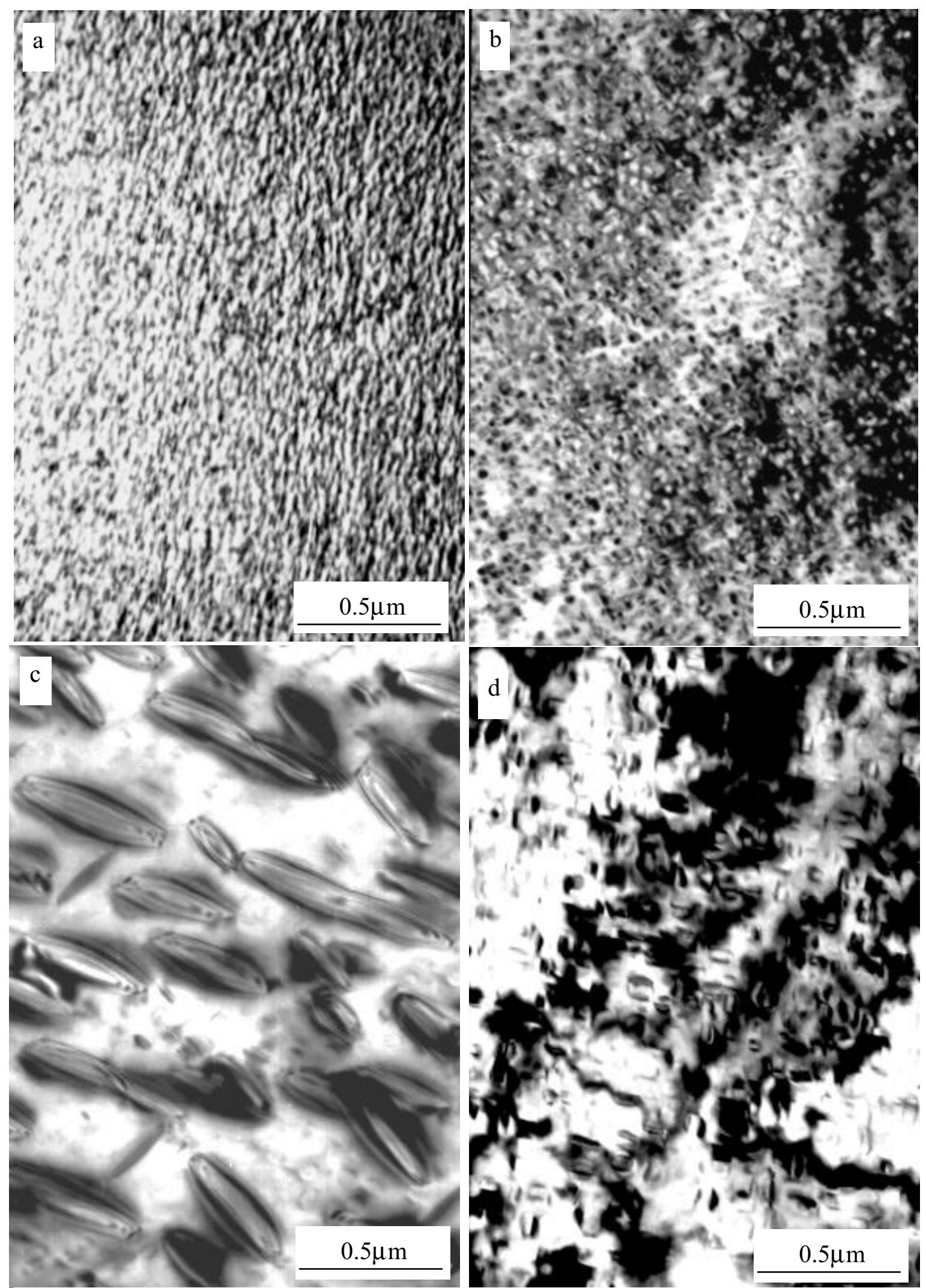

Fig.12 Structure stability comparison of $\gamma^{\prime \prime}+\gamma^{\prime}$ strengthening phases in Alloy 718 , and a modified 718 alloy with high content of $\mathrm{Al}(1 \% \mathrm{wt})$ at as heat treated condition(a,b) and after long time aging at $680^{\circ} \mathrm{C}$ for $1000 \mathrm{hrs}(\mathrm{c}, \mathrm{d})$

alloys. Fig. 12 as an example clearly shows that a modified 718 alloy with higher content of Al $\left(\sim 1 \%\right.$ wt) characterizes with much better structure stability at $680{ }^{\circ} \mathrm{C}$ even after $1000 \mathrm{~h}$ long time aging. At as heat treated condition the average size of $\gamma^{\prime \prime}$ precipitates in alloy 718 and modified 
718 alloy both are almost in the range of 20-30nm. However,after $680^{\circ} \mathrm{C}, 1000 \mathrm{~h}$ aging $\gamma^{\prime \prime}$ in Alloy 718 grows to a range of $300-400 \mathrm{~nm}$ (see Fig.12c), it is almost 10-20 times larger than the $\gamma^{\prime \prime}$ size at as heat treated condition. The main strengthening phases in this modified 718 alloy are $\gamma^{\prime \prime}+\gamma^{\prime}$ in associated precipitation at as heat treated condition (Fig.12b). During $680^{\circ} \mathrm{C}$ long time aging the coarsening rate of $\gamma^{\prime \prime}+\gamma^{\prime}$ in the morphology of associated precipitation is very slow. After $1000 \mathrm{~h}$ aging at $6800^{\circ} \mathrm{C}$ the average size of $\gamma^{\prime \prime} / \gamma^{\prime}$ grows to less than $100 \mathrm{~nm}$ (Fig 12d), which is only about 3-4 times larger than the size of precipitates at as heat treated condition. If the Al content is raised to a higher level (such as $1.5 \% \mathrm{wt}$ in Allvac 718 PlusA), the main strengthening phase is changed from $\gamma^{\prime \prime}$ in Alloy 718 to $\gamma^{\prime}$ in this modified 718 Alloy. Long time structure stability study at $760{ }^{\circ} \mathrm{C}$ result ${ }^{[19]}$ shows that the average size of $\gamma^{\prime}$ after $760{ }^{\circ} \mathrm{C}, 500 \mathrm{~h}$ aging is still less than $100 \mathrm{~nm}$. In result of that this alloy characterizes with unique stress rupture properties at $700^{\circ} \mathrm{C}$.

\section{Conclusions}

For structure stability improvement and promoting precipitation strengthening effect in development of modified 718 type Ni-base superalloys to be used beyond $650{ }^{\circ} \mathrm{C}$, one of the simplest and effective methods is to control the $\gamma^{\prime \prime}$ and $\gamma^{\prime}$ phase precipitation behavior by means of the adjustment of $\mathrm{Nb}$, Ti and $\mathrm{Al}$. The important results of this study can be concluded as follows:

1. High temperature strengths such as tensile and stress rupture properties both are very dependent on the sum of $(\mathrm{Al}+\mathrm{Ti}+\mathrm{Nb}) \%$ at in modified 718type alloys. For the purpose of high strengths the sum of $(\mathrm{Al}+\mathrm{Ti}+\mathrm{Nb}) \%$ at should be raised from 5.5-5.6\%at for conventional Alloy 718 to $7-7.5 \%$ at at high content of $\mathrm{Nb}(5.4-5.5 \mathrm{wt} \%)$ for the new modified 718 type alloys.

2. The strengthening effect is sensitively dependent on the fraction of $\gamma^{\prime \prime} / \gamma^{\prime}$ in 718 type alloys. The weight fraction of $\gamma^{\prime \prime} / \gamma^{\prime}$ for new modified 718 type alloys with high sum of $(\mathrm{Al}+\mathrm{Ti}+\mathrm{Nb}) \%$ at can reach the high level of about $20 \%$, which is almost $1 / 3$ fraction more than that in conventional 718 Alloy (14-15\% $\gamma^{\prime \prime}$ and $\gamma^{\prime}$ only).

3. From viewpoint of high temperature long time structure stability improvement of modified 718 type alloy, it requires an associated precipitation or compact morphology of $\gamma^{\prime \prime}+\gamma^{\prime}$ and even main $\gamma^{\prime}$ precipitation, whose growth rates are lower than separately precipitated $\gamma^{\prime \prime}$ and $\gamma^{\prime}$ (as in conventional 718Alloy) at higher temperatures beyond $650{ }^{\circ} \mathrm{C}$. To fulfill this requirement, the $\mathrm{Al}$ content should be raised to a higher level $(1-1.5 \% \mathrm{wt})$, but Ti content is still kept at a reasonable level (around $1 \% \mathrm{wt}$ or less). It results to rais e the ratio of $(\mathrm{Al}+\mathrm{Ti}) / \mathrm{Nb}$ (in $1.1-1.4)$ and $\mathrm{Al} / \mathrm{Ti}$ (higher than 1.5) for promoting the stable $\gamma^{\prime}$ precipitation.

\section{Acknowledgements}

University authors greatly appreciate financial support from National Science Foundation of China and recently partial support from CBMM Brasil. Appreciations also to ATI Allvac for offering longtime aging samples of Allvac 718Plus and support for 718Plus structure stability study.

\section{References}

[1] H. L. Eiselstein, "Metallurgy of a Columbium-Hardened Nickel-Chromium-Iron Alloy", ASTM Special Technical Publication (1965), P62 
[2] R.Cozar and A. Pineau, "Morphology of $\gamma^{\prime}$ and $\gamma^{\prime}$ Precipitates and Thermal Stability of Inconel 718 Type Alloys", Metall. Trans. 4(1973), P47

[3] J. P. Collier, S. H. Wong, J. C. Philips and J. K. Tien, "The Effect of Varying Al, Ti and $\mathrm{Nb}$ Content on the Phase Stability of Inconel 718", Metall. Trans., 19A(1988)p1657

[4] J.P.Collier, A.O. Selius and J. K. Tien, "On Developing a Microstructurally and Thermally Stable Iron-Nickel Base Superalloy”, Superalloys 1988, Ed., Q.S. Riechman et al, TMS(1988), P43

[5] E. Guo, F. Xu and E. A. Loria, "Improving Thermal Stability of Alloy 718 via Small Modifications in Composition", Superalloy 718-Metallurgy and Applications, TMS(1989), p567

[6] Encai. Guo, Fengqin. Xu and E. A. Loria, "Further Studies on Thermal Stability of Modifid 718 Alloys", Superalloys 718, 625, 706 and Various Derivatives, TMS(1994),p721

[7] K. M. Chang and A. H. Nahm, Rene220: 100 F Improvement Over Alloy 718, Superalloy718 - Metallurgy and Applications, TMS(1989) p631

[8] W. R. Sun, S. R. Guo, D. Z. Lu and Z. Q. Hu, "Effect of Phosphorous on the Microstructure and Stress Rupture Properties in an Fe-Ni-Cr Base Superalloy", Metallurgical and Materials Transactions A, 28A(1997), p649

[9] Wei-Di Cao, R. Kennedy, "Role of Chemistry in 718 Type Alloy-Allvac ${ }^{\circledR} 718$ Plus ${ }^{\mathrm{TM}}$ Alloy Development", Superalloys 2004, TMS(2004)p91

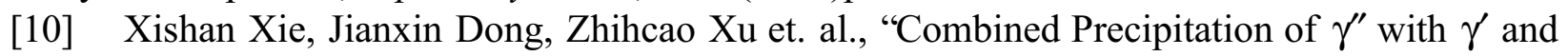
Stability Study in Modified Inconel 718 Alloys", Proceedings of PRICM-1, TMS(1992), p857

[11] J. Dong, X. Xie, S. Zhang, "Influence of Associated and Separated Precipitation of $\gamma^{\prime}$ and $\gamma^{\prime}$ on Structure Stability in Inconel 718 and Modified Alloys", Acta Metallurgica Sinica (English Ed.),6A(1993) p410

[12] J. Dong, X. Xie and S. Zhang, "Enhancement of Thermal Structure Stability in a NiBase Superalloy", Script Metallurgica 28(1993) p1477

[13] Xishan Xie, Qiang Liang, Jianxin Dong, Weigang Meng, Zhichao Xu, Mengzhe Chen, Fugang Wang, Yu Cai, Junshan Zhang, Ning Wang, E. Andrieu, A. Pineau, "Investigation on High Thermal Stability and Creep Resistant Modified Inconel 718 with Combined Precipitation of $\gamma^{\prime \prime}$ and $\gamma^{\prime \prime}$, Superalloys 718, 625, 706 and Various Derivatives, TMS (1994)p711

[14] Xie X. Dong J et al., "Investigation on Modified Nickel-Base Superalloy with Combined Precipitation of $\gamma^{\prime \prime}$ and $\gamma^{\prime}$," Trans. of Metal Heat Treatment (in Chinese)18(1997)p37

[15] Xishan Xie, Zhichao Xu, Bo Qu, Guoliang Chen, John Radavich, "The Role of Mg on Structure and Mechanical Properties in Alloy 718", Superalloys 1988, TMS(1988)p635

[16] X. Xie, Y. Zhang, Z. Xu, K. Ni, Y. Zhu, T. Zhang, Y. Tong, X. Ning, S. Zhang, J. F. Radavich, Effect of Oxygen, "Nitrogen and Magnesium on Segregation, Solidification and Mechanical Properties in Alloy 718", Superalloys 718, 625, 706 and Various Derivatives, TMS(1991)p241

[17] Xishan xie, Xingbo Liu et al., "The Role of Phosphorous and Sulfur in Inconel 718", Superalloys 1996, TMS(1996)p599

[18] Xishan Xie, Xingbo Liu, Jianxin Dong et al., 'Segregation Behavior of Phosphorous and Its Effect on Microstructure and Mechanical Properties in Alloy System NiCr-Fe-Mo-Nb-TiAl", Superalloys 718, 625, 706 and Various Derivatives, TMS(1997)p553

[19] X. Xie, G. Wang, J. Dong et al., "Structure Stability Study on a Newly Developed

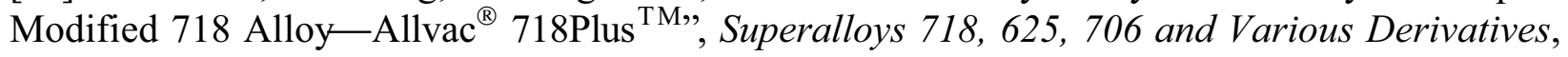
$\operatorname{TMS}(2005)$

[20] G.Wang, X. Xie, J. Dong, "Report on Joint Project of the Microstructure Stability Study on Alloys Allvac 718PlusA, 718PlusB and 718 after Long Time Thermal Exposure”, University of Science \& Technology Beijing and ATI Allvac (2005)

Allvac and 718Plus are trademarks of ATI Properties, Inc. 